\title{
СРАВНИТЕЛЬНЫЙ АНАЛИЗ СРЕДНЕМЕСЯЧНОЙ РЕАЛЬНОЙ ЗАРАБОТНОЙ ПЛАТЫ РАБОТНИКОВ ОРГАНИЗАЦИЙ В РАЗРЕЗЕ ВИДОВ ЭКОНОМИЧЕСКОЙ ДЕЯТЕЛЬНОСТИ ПО ИРКУТСКОЙ ОБЛАСТИ
}

\author{
Е. В. Балдынова, С. А. Малютина \\ Байкальский государственный университет, г. Иркутск, Российская Федерация
}

Информация о статье

Дата поступления

13 июня 2018 г.

Дата принятия к печати 14 августа 2018 г.

Дата онлайн-размещения 3 сентября 2018 г.

\section{Ключевые слова}

Заработная плата; оплата труда; виды экономической деятельности; номинальная заработная плата; реальная заработная плата; индекс потребительских цен; среднемесячная заработная плата; среднемесячная реальная заработная плата

\begin{abstract}
Аннотация
Размер заработной платы как денежного вознаграждения за труд зависит от многих факторов, которые можно объединить в следующие группы: территориальные, организационно-правовые, гендерные, профессионально-образовательные и др. В статье рассматривается зависимость размера среднемесячной реальной заработной платы от вида экономической деятельности. Кроме того, изучается динамика и степень вариации среднемесячной реальной заработной платы в разрезе видов экономической деятельности по Иркутской области. В результате анализа реальной среднемесячной заработной платы по видам экономической деятельности были выделены ее группы по уровню.
\end{abstract}

\section{COMPARATIVE ANALYSIS OF AVERAGE MONTHLY REAL PAY OF CORPORATE EMPLOYEES IN IRKUTSK OBLAST IN TERMS OF TYPES OF ECONOMIC ACTIVITY}

\section{Evgeniia V. Baldynova, Svetlana A. Malyutina \\ Baikal State University, Irkutsk, the Russian Federation}

\section{Article info}

Received

June 13, 2018

Accepted

August 14, 2018

Available online

September 3, 2018

\section{Keywords}

Salary and emoluments;

remuneration of labour; type

of economic activity; nominal pay;

real pay; consumer price index; average monthly pay; average monthly real pay

\begin{abstract}
The rate of salary and remuneration as monetary compensation for labour depends on many factors that can be combined into the following groups: territorial, organizational and legal, gender, professional and educational, etc. The article examines the dependence of the average monthly real wage on the type of economic activity. In addition, the authors study the dynamics and degree of variation of the average monthly real wages in terms of types of economic activity in Irkutsk Oblast. Having analyzed the real average monthly wages by types of economic activity, the authors categorized them into several groups according to their scale.
\end{abstract}

Информация об уровне оплаты труда представляет собой важный элемент функционирования рынка: в ней заинтересованы все субъекты хозяйственной деятельности.
Кроме того, она необходима для прогнозирования и выработки социально-экономической политики региона [1]. Анализ заработной платы заключается не только в определе- 
нии динамики показателя во времени, но и в изучении ее диффференциации по различным признакам.

Согласно существующим подходам, выделяют следующие факторы, направленные на диффреренциацию заработной платы [2, c. 18-96]:

- субъекты РФ;

- виды экономической деятельности;

- формы собственности;

- гендерные различия;

- уровень образования;

- профессиональные аспекты.

По мнению большинства авторов, заработная плата в России рассматривается в тесной взаимосвязи с вышеперечисленными факторами. При этом необходимо отметить, что в связи с изменениями, происходящими в экономике, менялось влияние каждого из них. Так, А. Л. Лукьянова приводит данные о том, что в период с 1992 по 2009 г. доля работников с высшим образованием увеличилась с 16 до 29 \%. Этому способствовали межотраслевые сдвиги в экономике, технологические изменения внутри отрасли, техническая модернизация производства и бизнес-процессов, быстрое развитие высокотехнологичных отраслей. По ее мнению, переход России на рыночную экономику привел к возникновению предприятий различных форм собственности, что повлекло за собой различия в оплате труда наемных работников [3, с. 40-46].

Относительно межрегиональных различий в заработной плате следует сказать, что они резко возросли с 1992 по 1995 г. По исследованиям того периода, средняя зарплата в самом бедном регионе была в 10 раз ниже, чем в богатом. В последнее время дифференциация оплаты труда по субъектам Российской Федерации стала постепенно сокращаться, но все же влияние данного фактора существенно. Это можно объяснить, во-первых, различным уровнем реструктуризации экономики субъекта РФ, во-вторых, движением денежного потока в регион или из региона, в-третьих, экономической специализацией субъекта, в-четвертых, наличием дотаций и субсидий от федерального центра.

В ходе исследования динамики дифференциации заработной платы в Российской Федерации А. Л. Лукьянова отмечает ее значительное увеличение в начале 1990-х гг. и после 1998 г., т. е. после финансового кризиса [3; 4]. В течение 2000-х гг. происходит некоторое снижение диффреренциации по различным показателям.

В то же время с учетом большой протяженности России, всего разнообразия ее субъектов высокая степень диффреренциации заработной платы в масштабе всей страны не означает, что различия в оплате труда каждого индивида в отдельности тоже существенны [5].

Среди фракторов, влияющих на различия в оплате труда, особое место отводится видам экономической деятельности [6]. Наиболее остро это ощущалось в период экономических реформ, когда в выгодном положении оказались добывающие отрасли, ориентированные на экспорт, а также финансовая деятельность, но в то же время такие виды, как сельское хозяйство, обрабатывающие отрасли, бюджетный сектор, находились в наихудшем положении относительно вышеперечисленных. Дифференциация заработной платы по видам экономической деятельности зависит от дифрференциации заработной платы по видам услуг [7]. Исходя из значимости данного направления был проведен статистический анализ среднемесячной реальной заработной платы в зависимости от вида экономической деятельности на примере Иркутской области.

Заработная плата - это денежное вознаграждение человеку за его труд. Она зависит от уровня квалификации работника, количества и качества выполняемой им работы и ее сложности [8]. При изучении заработной платы необходимо выделить два понятия: номинальная и реальная заработная плата. Номинальная - это начисленная заработная плата, а реальная - это фактическое количество товаров и услуг, которое работник может приобрести в зависимости от размера номинальной заработной платы [9, с. 159]. Поскольку цены на товары и услуги меняются постоянно, следовательно, реальная заработная плата зависит от их динамики. Поэтому она является точным измерителем уровня доходов. Исходя из этого для статистического анализа была выбрана реальная среднемесячная заработная плата.

Номинальная и реальная заработная платы взаимосвязаны друг с другом с помощью индекса цен. Расчет реальной заработной платы осуществляется по формуле

$$
3 \Pi_{p}=\frac{3 \Pi_{H}}{I_{\sigma}},
$$

где $3 \Pi_{p}$ - реальная заработная плата; $3 \Pi_{H}-$ номинальная заработная плата; $I_{6}-$ базисный индекс цен.

Размер номинальной среднемесячной заработной платы по видам экономической деятельности представлен в табл. 1. 
Динамика среднемесячной номинальной заработной платы по видам экономической деятельности в Иркутской области в 2009-2016 гг., р.'

\begin{tabular}{|c|c|c|c|c|c|c|c|c|}
\hline Вид экономической деятельности & 2009 & 2010 & 2011 & 2012 & 2013 & 2014 & 2015 & 2016 \\
\hline $\begin{array}{l}\text { Сельское хозяйство, охота и лесное } \\
\text { хозяйство }\end{array}$ & 12207 & 13346 & 16025 & 18697 & 21352 & 24775 & 28709 & 33400 \\
\hline Рыболовство, рыбоводство & 6837 & 5363 & 8425 & 4164 & 3846 & 4940 & 8527 & 11747 \\
\hline Добыча полезных ископаемых & 26804 & 33607 & 40360 & 45559 & 49761 & 55882 & 61087 & 67830 \\
\hline Обрабатывающие производства & 19881 & 22185 & 24850 & 26858 & 29279 & 32689 & 35533 & 38617 \\
\hline $\begin{array}{l}\text { Производство и распределение электро- } \\
\text { энергии, газа и воды }\end{array}$ & 23271 & 26874 & 28986 & 31899 & 34201 & 36789 & 38920 & 41306 \\
\hline Строительство & 17933 & 19564 & 21438 & 23927 & 24955 & 25160 & 23180 & 25889 \\
\hline $\begin{array}{l}\text { Оптовая и розничная торговля; ремонт } \\
\text { автотранспортных средств, мотоциклов, } \\
\text { бытовых изделий и предметов личного } \\
\text { пользования }\end{array}$ & 10144 & 14425 & 13557 & 14634 & 16734 & 17225 & 18081 & 19484 \\
\hline Гостиницы и рестораны & 9584 & 10707 & 12358 & 12622 & 13666 & 15294 & 16355 & 17238 \\
\hline Транспорт и связь & 23760 & 27900 & 30606 & 33760 & 36198 & 38143 & 39939 & 42164 \\
\hline Финансовая деятельность & 36305 & 42251 & 46194 & 49544 & 51854 & 53914 & 54205 & 60020 \\
\hline $\begin{array}{l}\text { Операции с недвижимым имуществом, } \\
\text { аренда и предоставление услуг }\end{array}$ & 18705 & 20706 & 21941 & 23806 & 26016 & 28736 & 31533 & 34021 \\
\hline $\begin{array}{l}\text { Государственное управление и обеспе- } \\
\text { чение военной безопасности; социальное } \\
\text { страхование }\end{array}$ & 27998 & 29424 & 31720 & 40055 & 46133 & 48321 & 47663 & 49326 \\
\hline Образование & 12166 & 12394 & 14396 & 18187 & 22851 & 24981 & 25160 & 25731 \\
\hline $\begin{array}{l}\text { Здравоохранение и предоставление } \\
\text { социальных услуг }\end{array}$ & 13996 & 15260 & 17251 & 20893 & 24471 & 27307 & 27607 & 28755 \\
\hline $\begin{array}{l}\text { Предоставление прочих коммунальных, } \\
\text { социальных и персональных услуг }\end{array}$ & 11006 & 12241 & 13585 & 15829 & 19226 & 22194 & 24098 & 24516 \\
\hline
\end{tabular}

Представленная среднемесячная заработная плата вычисляется согласно методике расчета среднемесячной начисленной заработной платы наемных работников [10].

Расчет реальной среднемесячной заработной платы осуществляется с помощью отношения номинальной среднемесячной заработной платы к индексу потребительских цен, пересчитанному к определенному периоду. Для таких преобразований воспользуемся информацией о динамике индекса потребительских цен (табл. 2).
В табл. 2 индекс потребительских цен представлен в процентах относительно предыдущего года, поэтому необходимо провести его преобразование к базисному периоду исходя из взаимосвязи цепных и базисных индексов:

$$
I_{6}=\Pi I_{4^{\prime}}
$$

где $I_{6}$ - базисный индекс цен; П І - произведение цепных индексов.

По нашим данным, 2008 год является базисным. В результате преобразования получим следующие данные, представленные в табл. 3.

\section{Динамика индекса потребительских цен по Иркутской области в 2009-2016 гг.}

\begin{tabular}{|l|c|c|c|c|c|c|c|c|}
\hline Показатель & 2009 & 2010 & 2011 & 2012 & 2013 & 2014 & 2015 & 2016 \\
\hline $\begin{array}{l}\text { Индекс потребительских цен, \% к предыдуще- } \\
\text { му году }\end{array}$ & 108,00 & 109,50 & 107,40 & 106,90 & 105,10 & 110,80 & 112,15 & 106,70 \\
\hline
\end{tabular}
" Составлена по данным Территориального органа Федеральной службы государственной статистики по Иркут-
ской области. URL: www.irkutskstat.gks.ru.

Динамика индекса потребительских цен по Иркутской области в 2009-2016 гг., приведенного к 2008 г.

\begin{tabular}{|c|c|c|c|c|c|c|c|c|}
\hline \multicolumn{1}{|c|}{ Показатель } & 2009 & 2010 & 2011 & 2012 & 2013 & 2014 & 2015 & 2016 \\
\hline $\begin{array}{l}\text { Индекс потребительских цен, \% } \\
\text { к 2008 г. }\end{array}$ & 108,00 & 118,26 & 127,01 & 135,77 & 142,69 & 158,10 & 177,31 & 189,19 \\
\hline
\end{tabular}


Используя показатели табл. 1 и 3 и фоормулу (1), пересчитаем номинальную среднемесячную заработную плату по видам экономической деятельности в реальную, приведенную к ценам 2008 г. Итоги расчетов представлены в табл. 4.

Для изучения изменения реальной среднемесячной заработной платы по видам экономической деятельности воспользуемся одним из методов статистики - методом относительных величин. Он дает возможность установить динамику изучаемого явления в относительном выражении. Для характеристики изменения явления во времени применим относительную величину динамики (темп роста). Когда имеется информация за несколько периодов, рас- чет может осуществляться двумя способами - определением цепных и базисных темпов ее роста.

$$
T_{4}=\frac{Y_{i}}{Y_{i-1}} \cdot 100,
$$

где $T_{4}$ - цепной темп роста; $Y_{i}$ - значение ряда динамики за текущее время; $Y_{i-1}-$ значение ряда динамики за предыдущее время.

$$
T_{\sigma}=\frac{Y_{i}}{Y_{0}} \cdot 100,
$$

где $T_{6}-$ базисный темп роста; $Y_{i}$ - значение ряда динамики за текущее время; $Y_{0}-$ значение ряда динамики за базисное время.

Результаты их расчетов представлены в табл. 5 и 6.

Таблица 4

Динамика среднемесячной реальной заработной платы по видам экономической деятельности в Иркутской области в 2009-2016 гг., р.

\begin{tabular}{|l|r|r|r|r|r|r|r|r|}
\hline \multicolumn{1}{|c|}{ Вид экономической деятельности } & 2009 & 2010 & 2011 & 2012 & 2013 & 2014 & 2015 & 2016 \\
\hline $\begin{array}{l}\text { Сельское хозяйство, охота и лесное } \\
\text { хозяйство }\end{array}$ & 11303 & 11285 & 12617 & 13771 & 14964 & 15670 & 16191 & 17654 \\
\hline Рыболовство, рыбоводство & 6331 & 4535 & 6633 & 3067 & 2695 & 3125 & 4809 & 6209 \\
\hline Добыча полезных ископаемых & 24819 & 28418 & 31777 & 33556 & 34874 & 35346 & 34452 & 35853 \\
\hline Обрабатывающие производства & 18408 & 18760 & 19565 & 19782 & 20519 & 20676 & 20040 & 20412 \\
\hline $\begin{array}{l}\text { Производство и распределение электро- } \\
\text { энергии, газа и воды }\end{array}$ & 21547 & 22725 & 22822 & 23495 & 23969 & 23269 & 21950 & 21833 \\
\hline Строительство & 16605 & 16543 & 16879 & 17623 & 17489 & 15914 & 13045 & 13684 \\
\hline $\begin{array}{l}\text { Оптовая и розничная торговля; ремонт } \\
\text { автотранспортных средств, мотоциклов, } \\
\text { бытовых изделий и предметов личного } \\
\text { пользования }\end{array}$ & 9393 & 12198 & 10674 & 10779 & 11728 & 10895 & 10197 & 10299 \\
\hline Гостиницы и рестораны & 8874 & 9054 & 9730 & 9297 & 9577 & 9674 & 9224 & 9111 \\
\hline Транспорт и связь & 22000 & 23592 & 24097 & 24866 & 25368 & 24126 & 22525 & 22287 \\
\hline Финансовая деятельность & 33616 & 35727 & 36370 & 36491 & 36340 & 34101 & 30571 & 31725 \\
\hline $\begin{array}{l}\text { Операции с недвижимым имуществом, } \\
\text { аренда и предоставление услуг }\end{array}$ & 17319 & 17509 & 17275 & 17534 & 18233 & 18176 & 17784 & 17982 \\
\hline $\begin{array}{l}\text { Государственное управление и обеспе- } \\
\text { чение военной безопасности; социальное } \\
\text { страхование }\end{array}$ & 25924 & 24881 & 24974 & 29502 & 32331 & 30564 & 26881 & 26072 \\
\hline Образование & 11265 & 10480 & 11335 & 13395 & 16014 & 15801 & 14190 & 13601 \\
\hline $\begin{array}{l}\text { Здравоохранение и предоставление } \\
\text { социальных услуг }\end{array}$ & 12959 & 12904 & 13582 & 15389 & 17150 & 17272 & 15570 & 15199 \\
\hline $\begin{array}{l}\text { Предоставление прочих коммунальных, } \\
\text { социальных и персональных услуг }\end{array}$ & 10191 & 10351 & 10696 & 11659 & 13474 & 14038 & 13591 & 12958 \\
\hline
\end{tabular}

Цепные темпы роста реальной среднемесячной заработной платы по видам экономической деятельности в 2009-2016 гг., \%

\begin{tabular}{|l|r|r|r|r|r|r|r|c|}
\hline \multicolumn{1}{|c|}{ Вид экономической деятельности } & 2009 & 2010 & 2011 & 2012 & 2013 & 2014 & 2015 & 2016 \\
\hline $\begin{array}{l}\text { Сельское хозяйство, охота и лесное } \\
\text { хозяйство }\end{array}$ & - & 99,84 & 111,80 & 109,15 & 108,66 & 104,72 & 103,32 & 109,04 \\
\hline Рыболовство, рыбоводство & - & 71,63 & 146,26 & 46,24 & 87,87 & 115,96 & 153,89 & 129,11 \\
\hline Добыча полезных ископаемых & - & 114,50 & 111,82 & 105,60 & 103,93 & 101,35 & 97,47 & 104,07 \\
\hline Обрабатывающие производства & - & 101,91 & 104,29 & 101,11 & 103,73 & 100,77 & 96,92 & 101,86 \\
\hline
\end{tabular}


Окончание табл. 5

\begin{tabular}{|l|r|r|r|r|r|r|r|r|}
\hline \multicolumn{1}{|c|}{ Вид экономической деятельности } & 2009 & 2010 & 2011 & 2012 & 2013 & 2014 & 2015 & 2016 \\
\hline $\begin{array}{l}\text { Производство и распределение электро- } \\
\text { энергии, газа и воды }\end{array}$ & - & 105,47 & 100,43 & 102,95 & 102,02 & 97,08 & 94,33 & 99,47 \\
\hline Строительство & - & 99,63 & 102,03 & 104,41 & 99,24 & 90,99 & 81,97 & 104,90 \\
\hline $\begin{array}{l}\text { Оптовая и розничная торговля; ремонт } \\
\text { автотранспортных средств, мотоциклов, } \\
\text { бытовых изделий и предметов личного } \\
\text { пользования }\end{array}$ & - & 129,86 & 87,51 & 100,98 & 108,80 & 92,90 & 93,59 & 101,00 \\
\hline Гостиницы и рестораны & $-102,03$ & 107,47 & 95,55 & 103,01 & 101,01 & 95,35 & 98,77 \\
\hline Транспорт и связь & $-107,24$ & 102,14 & 103,19 & 102,02 & 95,10 & 93,36 & 98,94 \\
\hline Финансовая деятельность & - & 106,28 & 101,80 & 100,33 & 99,59 & 93,84 & 89,65 & 103,77 \\
\hline $\begin{array}{l}\text { Операции с недвижимым имуществом, } \\
\text { аренда и предоставление услуг }\end{array}$ & - & 101,10 & 98,66 & 101,50 & 103,99 & 99,69 & 97,84 & 101,11 \\
\hline $\begin{array}{l}\text { Государственное управление и обеспе- } \\
\text { чение военной безопасности; социальное } \\
\text { страхование }\end{array}$ & - & 95,98 & 100,37 & 118,13 & 109,59 & 94,53 & 87,95 & 96,99 \\
\hline Образование & - & 93,03 & 108,16 & 118,17 & 119,55 & 98,67 & 89,80 & 95,85 \\
\hline $\begin{array}{l}\text { Здравоохранение и предоставление } \\
\text { социальных услуг }\end{array}$ & - & 99,58 & 105,25 & 113,30 & 111,44 & 100,71 & 90,15 & 97,62 \\
\hline $\begin{array}{l}\text { Предоставление прочих коммунальных, } \\
\text { социальныхи персональных услуг }\end{array}$ & - & 101,57 & 103,33 & 109,00 & 115,57 & 104,19 & 96,82 & 95,34 \\
\hline
\end{tabular}

Базисные темпы роста реальной среднемесячной заработной платы по видам

Таблица 6 экономической деятельности в 2009-20016 гг., \%

\begin{tabular}{|l|r|r|r|r|r|r|r|r|}
\hline \multicolumn{1}{|c|}{ Вид экономической деятельности } & 2009 & 2010 & 2011 & 2012 & 2013 & 2014 & 2015 & 2016 \\
\hline $\begin{array}{l}\text { Сельское хозяйство, охота и лесное } \\
\text { хозяйство }\end{array}$ & - & 99,84 & 111,63 & 121,83 & 132,39 & 138,64 & 143,25 & 156,19 \\
\hline Рыболовство, рыбоводство & - & 71,63 & 104,77 & 48,44 & 42,57 & 49,36 & 75,96 & 98,07 \\
\hline Добыча полезных ископаемых & - & 114,50 & 128,03 & 135,20 & 140,51 & 142,42 & 138,81 & 144,46 \\
\hline Обрабатывающие производства & - & 101,91 & 106,29 & 107,46 & 111,47 & 112,32 & 108,87 & 110,89 \\
\hline $\begin{array}{l}\text { Производство и распределение электро- } \\
\text { энергии, газа и воды }\end{array}$ & - & 105,47 & 105,92 & 109,04 & 111,24 & 107,99 & 101,87 & 101,33 \\
\hline Строительство & - & 99,63 & 101,65 & 106,13 & 105,32 & 95,84 & 78,56 & 82,41 \\
\hline $\begin{array}{l}\text { Оптовая и розничная торговля; ремонт } \\
\text { автотранспортных средств, мотоциклов, } \\
\text { бытовых изделий и предметов личного } \\
\text { пользования }\end{array}$ & - & $-129,86$ & 113,64 & 114,76 & 124,86 & 115,99 & 108,56 & 109,65 \\
\hline Гостиницы и рестораны & $-102,03$ & 109,65 & 104,77 & 107,92 & 109,02 & 103,94 & 102,67 \\
\hline Транспорт и связь & - & 107,24 & 109,53 & 113,03 & 115,31 & 109,66 & 102,39 & 101,30 \\
\hline Финансовая деятельность & - & 106,28 & 108,19 & 108,55 & 108,10 & 101,44 & 90,94 & 94,37 \\
\hline $\begin{array}{l}\text { Операции с недвижимым имуществом, } \\
\text { арендаи предоставление услуг }\end{array}$ & - & 101,10 & 99,75 & 101,24 & 105,28 & 104,95 & 102,68 & 103,83 \\
\hline $\begin{array}{l}\text { Государственное управление и обеспе- } \\
\text { чение военной безопасности; социальное } \\
\text { страхование }\end{array}$ & - & 95,98 & 96,34 & 113,80 & 124,71 & 117,90 & 103,69 & 100,57 \\
\hline Образование & - & 93,03 & 100,62 & 118,91 & 142,16 & 140,27 & 125,97 & 120,74 \\
\hline $\begin{array}{l}\text { Здравоохранение и предоставление } \\
\text { социальных услуг }\end{array}$ & - & 99,58 & 104,81 & 118,75 & 132,34 & 133,28 & 120,15 & 117,29 \\
\hline $\begin{array}{l}\text { Предоставление прочих коммунальных, } \\
\text { социальных и персональных услуг }\end{array}$ & - & 101,57 & 104,96 & 114,40 & 132,21 & 137,75 & 133,36 & 127,15 \\
\hline
\end{tabular}

Анализ результатов расчета цепных темпов роста реальной среднемесячной заработной платы свидетельствует о неоднородном изменении показателя по годам. В таких видах экономической деятельности, как «Рыболовство, рыбоводство», «Оптовая и розничная торговля...», «Образо- вание», эти колебания происходят более заметно.

Относительно базисного года наблюдается рост изучаемого явления практически до 2014 г. Однако необходимо отметить, что это увеличение зависит как от вида экономической деятельности, так и от года. 
Опираясь только на темпы роста, нельзя осуществить полноценный статистический анализ данной информации. Для более глубокого изучения материала необходимо применить и другие методы, одним из которых является вариационный анализ, позволяющий оценить уровень колеблемости значений признака относительно средней величины и тем самым установить однородность совокупности. Это связано с тем, что средняя величина дает лишь обобщенную характеристику признака, но не показывает колеблемость отдельных значений по отношению к себе.

Для вариационного анализа среднемесячной реальной заработной платы по видам экономической деятельности в Иркутской области выберем следующие годы: 2009, 2013 и 2015-й. Выбор этих периодов объясняется тем, что в 2009 г. наблюдалась ситуация, вызванная мировым финансовым кризисом 2008 г. В 2013 г. в экономике страны отмечалась стагнация. В 2015 г. замечены признаки рецессии. К тому же эти периоды наиболее полно характеризуют уровень диффреренциации реальной среднемесячной заработной платы по видам экономической деятельности.

Одним из простых показателей вариации является ее размах, который вычисляется по формуле

$$
R=x_{\max }-x_{\min }
$$

где $x_{\max }$ - максимальная среднемесячная реальная заработная плата по видам экономической деятельности в Иркутской области; $x_{\min }$ - минимальная среднемесячная реальная заработная плата по видам экономической деятельности в Иркутской области.
Расчет аналитического показателя проведен на основе данных табл. 4.

Размах вариации составил:

- в 2009 г. $R=33626-6331=27285$ р.;

- в 2013 г. $R=36340-2695=33645$ р.;

- в 2015 г. $R=34452-4809=29643$ р.

Необходимо отметить, что максимальное значение среднемесячной реальной заработной платы в 2009 и 2013 гг. относилось к финансовой деятельности, а в 2015 г. - к добыче полезных ископаемых. Минимальное значение среднемесячной реальной заработной платы на протяжении изучаемых периодов оставалось неизменным и относилось к рыболовству, рыбоводству.

Поскольку размах вариации зависит от двух крайних величин (максимума и минимума), полагаться только на его значение в анализе недостаточно. Поэтому для исследования изучаемого вопроса осуществим расчет среднеквадратичного отклонения и коэфрфициента вариации.

Для оценки степени отклонения от среднеобластного значения показателя рассчитаем среднеквадратичное отклонение:

$$
\sigma= \pm \sqrt{\frac{\sum(x-\bar{x})^{2}}{n}}
$$

где $\sigma$ - среднеквадратичное отклонение; $x$ - среднемесячная реальная заработная плата по видам экономической деятельности в Иркутской области; $\overline{\boldsymbol{x}}-$ среднемесячная реальная заработная плата в целом в Иркутской области; $n-$ количество видов экономической деятельности.

Для удобства расчета показателя осуществим его пошаговое определение (табл. 7).

Расчет значений для определения среднеквадратичного отклонения

Таблица 7

\begin{tabular}{|l|r|r|r|r|r|r|}
\hline \multirow{2}{*}{ Значение } & \multicolumn{2}{|c|}{2009} & \multicolumn{2}{|c|}{2013} & \multicolumn{2}{|c|}{2015} \\
\cline { 2 - 7 } & \multicolumn{1}{|c|}{$x$} & $(x-\bar{x})^{2}$ & \multicolumn{1}{c|}{$x$} & $(x-\bar{x})^{2}$ & \multicolumn{1}{c|}{$x$} & $(x-\bar{x})^{2}$ \\
\hline Иркутская область $(\bar{x})$ & 16845 & - & 20359 & - & 18445 & - \\
\hline $\begin{array}{l}\text { Сельское хозяйство, охота и лесное } \\
\text { хозяйство }\end{array}$ & 11303 & 30713764 & 14964 & 29106025 & 16191 & 5080516 \\
\hline Рыболовство, рыбоводство & 6331 & 110544196 & 2695 & 312016896 & 4809 & 185940496 \\
\hline Добыча полезных ископаемых & 24819 & 63584676 & 34874 & 210685225 & 34452 & 256224049 \\
\hline Обрабатывающие производства & 18408 & 2442969 & 20519 & 25600 & 20040 & 2544025 \\
\hline $\begin{array}{l}\text { Производство и распределение электро- } \\
\text { энергии, газа и воды }\end{array}$ & 21547 & 22108804 & 23969 & 13032100 & 21950 & 12285025 \\
\hline Строительство & 16605 & 57600 & 17489 & 8236900 & 13045 & 29160000 \\
\hline $\begin{array}{l}\text { Оптовая и розничная торговля; ремонт } \\
\text { автотранспортных средств, мотоциклов, } \\
\text { бытовых изделий и предметов личного } \\
\text { пользования }\end{array}$ & 9393 & 55532304 & 11728 & 74494161 & 10197 & 68029504 \\
\hline Гостиницы и рестораны & 8874 & 63536841 & 9577 & 116251524 & 9224 & 85026841 \\
\hline
\end{tabular}


Окончание табл. 7

\begin{tabular}{|l|r|r|r|r|r|r|}
\hline \multirow{2}{*}{ Значение } & \multicolumn{2}{|c|}{2009} & \multicolumn{2}{|c|}{2013} & \multicolumn{2}{c|}{2015} \\
\cline { 2 - 7 } & \multicolumn{1}{|c|}{$x$} & \multicolumn{1}{c|}{$(x-\bar{x})^{2}$} & \multicolumn{1}{c|}{$x$} & \multicolumn{1}{c|}{$(x-\bar{x})^{2}$} & \multicolumn{1}{c|}{$x$} & $(x-\bar{x})^{2}$ \\
\hline Транспорт и связь & 22000 & 26574025 & 25368 & 25090081 & 22525 & 16646400 \\
\hline Финансовая деятельность & 33616 & 281266441 & 36340 & 255392361 & 30571 & 147039876 \\
\hline $\begin{array}{l}\text { Операции с недвижимым имуществом, } \\
\text { аренда и предоставление услуг }\end{array}$ & 17319 & 224676 & 18233 & 4519876 & 17784 & 436921 \\
\hline $\begin{array}{l}\text { Государственное управление и } \\
\text { обеспечение военной безопасности; } \\
\text { социальное страхование }\end{array}$ & 25924 & 82428241 & 32331 & 143328784 & 26881 & 71166096 \\
\hline Образование & 11265 & 31136400 & 16014 & 18879025 & 14190 & 18105025 \\
\hline $\begin{array}{l}\text { Здравоохранение и предоставление } \\
\text { социальных услуг }\end{array}$ & 12959 & 15100996 & 17150 & 10297681 & 15570 & 8265625 \\
\hline $\begin{array}{l}\text { Предоставление прочих коммунальных, } \\
\text { социальных и персональных услуг }\end{array}$ & 10191 & 44275716 & 13474 & 47403225 & 13591 & 23561316 \\
\hline Итого & - & 829527649 & - & 1268759464 & - & 929511715 \\
\hline
\end{tabular}

Среднеквадратичное отклонение для 2009 г.: $\sigma= \pm \sqrt{\frac{829527649}{15}}= \pm 7436 \mathrm{p}$.

Среднеквадратичное отклонение для 2013 г.: $\sigma= \pm \sqrt{\frac{1268759464}{15}}= \pm 9197 \mathrm{p}$.

Среднеквадратичное отклонение для 2015 г.: $\sigma= \pm \sqrt{\frac{929511715}{15}}= \pm 7872 \mathrm{p}$.

Исходя из результатов вычислений, можно сделать вывод о том, что наибольшее отклонение от среднего уровня реальной заработной платы наблюдалось в 2013 г. - \pm 9197 р., в 2015 г. разрыв несколько сократился и составил \pm 7872 р. А в 2009 г. он был самый минимальный из трех представленных - \pm 7436 р.

Среднеквадратичное отклонение относится к группе абсолютных показателей вариации, которые могут зависеть от различных фракторов, поэтому необходимо определить группу относительных величин, среди которых особое место отводится коэффициенту вариации. Он характеризует глубину вариации и степень однородности совокупности. Его расчет проводится по формуле

$$
V= \pm \frac{\sigma}{\bar{x}} \cdot 100
$$

где $V$ - коэфффициент вариации; $\sigma$ - среднеквадратичное отклонение; $\bar{X}-$ среднемесячная реальная заработная плата в целом по Иркутской области.

Коэффициент вариации для 2009 г.: $V= \pm \frac{7436}{16845} \cdot 100= \pm 44,1 \%$.

Коэффрициент вариации для 2013 г.: $V= \pm \frac{9197}{20359} \cdot 100= \pm 45,2 \%$.
Коэффрициент вариации для 2015 г.: $V= \pm \frac{7872}{18445} \cdot 100= \pm 42,7 \%$.

В результате проведенных расчетов можно сделать вывод о высоком отклонении среднемесячных заработных плат по видам экономической деятельности от среднего значения по Иркутской области, о чем свидетельствуют коэффрициенты вариации, значения которых свыше 33 \%. Это обусловлено уровнем диффреренциации средней заработной платы по видам экономической деятельности и долей представленных отраслей в общем объеме валового регионального продукта. Поскольку Иркутская область обладает большими запасами природных ресурсов, следовательно, наибольший удельный вес занимают добывающие и обрабатывающие производства. Данная тенденция характерна не только для области, но и для страны в целом. Так, фринансовая деятельность и государственное управление отличаются высокой заработной платой, а образование, здравоохранение - около среднего уровня по области.

В результате анализа реальной среднемесячной заработной платы по видам экономической деятельности были выделены ее группы по уровню: высокий (1), средний (2), низкий (3) (табл. 8). Для осуществления данной группировки было использовано правило формирования групп по количественному непрерывному признаку. Для выделения групп рассчитывается шаг интервала $i$ по формуле

$$
i=\frac{x_{\max }-x_{\min }}{n},
$$

где $X_{\text {max }}$ - максимальное значение средней заработной платы; $X_{\min }$ - минимальное зна- 
чение средней заработной платы; $n-$ количество групп.

Рассчитаем для каждого года шаг интервала и границы интервалов:

$$
\text { Для } 2009 \text { г.: } i=\frac{33616-6331}{3}=9095 \text {, }
$$

следовательно, границы интервалов следующие: низкий уровень 6331 - 15426 р.; средний уровень 15426 - 24521 р.; высокий уровень $24521-33616 \mathrm{p}$.

$$
\text { Для } 2013 \text { г.: } i=\frac{36340-2695}{3}=11215 \text {, }
$$

следовательно, границы интервалов следующие: низкий уровень 2695 - 13910 р.; средний уровень 13910 - 25125 р.; высокий уровень $25125-36340 \mathrm{p}$.

$$
\text { Для } 2015 \text { г.: } i=\frac{34452-4809}{3}=9881 \text {, }
$$

следовательно, границы интервалов следующие: низкий уровень 4 809-14 690 р.; средний уровень 14 690-24 571 р.; высокий уровень $24571-34452 \mathrm{p}$.

Результаты распределения представлены в табл. 8.

Распределение видов экономической деятельности по уровню реальной среднемесячной

\begin{tabular}{|c|c|c|c|}
\hline Высокий (1) & $\begin{array}{l}\text { 1. Финансовая деятельность } \\
\text { 2. Государственное } \\
\text { управление и обеспечение } \\
\text { военной безопасности; } \\
\text { социальное страхование } \\
\text { 3. Добыча полезных } \\
\text { ископаемых }\end{array}$ & $\begin{array}{l}\text { 1. Финансовая деятельность } \\
\text { 2. Добыча полезных ископа- } \\
\text { емых } \\
\text { 3. Государственное } \\
\text { управление и обеспечение } \\
\text { военной безопасности; } \\
\text { социальное страхование } \\
\text { 4. Транспорт и связь }\end{array}$ & $\begin{array}{l}\text { 1. Добыча полезных } \\
\text { ископаемых } \\
\text { 2. Финансовая деятель- } \\
\text { ность } \\
\text { 3. Государственное } \\
\text { управление и обеспече- } \\
\text { ние военной безопас- } \\
\text { ности; социальное } \\
\text { страхование }\end{array}$ \\
\hline
\end{tabular}

Таблица 8 заработной платы 
Нумерация отраслей в табл. 8 характеризует их место в рейтинге по уровню средней заработной платы: 1 - самое высокое значение средней заработной платы, последнее значение нумерации - самая низкая величина.

Сравнительный анализ уровней реальной среднемесячной заработной платы по видам экономической деятельности позволяет сделать вывод о том, что в указанные годы значительных колебаний не наблюдалось. В первой группе, с высоким уровнем, присутствуют одни и те же отрасли, за исключением 2013 г. , когда в нее добавилась отрасль транспорта и связи. К 2015 г. лидирующее место стала занимать добыча полезных ископаемых.

Во второй группе в 2013 г. наблюдается увеличение числа отраслей. Свое место по сравнению с 2009 г. улучшили такие виды экономической деятельности, как здравоохранение и предоставление социальных услуг, сельское хозяйство, охота и лесное хозяйство, образование. Но в 2015 г. образование снова понизилось в рейтинге.

В третьей группе в 2009 г. мы видим самое большое количество отраслей с низким уровнем реальной среднемесячной заработной платы. К 2013 г. некоторые виды экономической деятельности повысили свое место в рейтинге, но к 2015 г. свой рейтинг понизили две отрасли - это образование и строительство.
Исходя из анализа данных о распределении реальной среднемесячной заработной платы по видам экономической деятельности можно сделать вывод о том, что вариация отклонения от среднего уровня по области достаточно высокая (от 42,7 до 45,2 \%). Это объясняется различием в уровнях развития отраслей в области. При этом группировка отраслей демонстрирует наиболее низкооплачиваемые и высокооплачиваемые виды экономической деятельности, при этом по годам изменения незначительные. Эта же тенденция наблюдается по стране в целом.

Таким образом, одним из значимых факторов, влияющих на диффференциацию заработной платы, является вид экономической деятельности. В регионе наблюдается преимущественно сырьевая ориентация экономики, область специализируется в большей степени на торгово-посреднических функциях. Поэтому уровень заработной платы в этих видах деятельности гораздо выше, чем в остальных. Непростая ситуация наблюдается в социальной сфере - образование, здравоохранение, а также в гостиничном и ресторанном бизнесе, рыболовстве и рыбоводстве. Данные обстоятельства требуют особого внимания при разработке государственной и муниципальной программ развития Иркутской области.

\section{СПИСОК ИСПОЛЬЗОВАННОЙ ЛИТЕРАТУРЫ}

1. Озерникова Т. Г. Основные проблемы оценки конкурентоспособности политики оплаты труда в России / Т. Г. Озерникова, М. А. Пономарчук // Известия Байкальского государственного университета. - 2016. T. 26, № 5. - C. 739-749. - DOI: 10.17150/2500-2759.2016.26(5).739-749.

2. Заработная плата в России: эволюция и дифференциация / под ред. В. Е. Гимпельсона, Р. И. Капелюшникова. - М. : Высш. шк. экономики, 2008. - 575 с.

3. Лукьянова А. Л. Дифференциация заработных плат в России (1991-2008 гг.): факты и объяснения / А. Л. Лукьянова. - М. : Высш. шк. экономики, 2010. - 68 с.

4. Лукьянова А. Л. Неравенство заработков: фактор неформальности (2000-2010 гг.) / А. Л. Лукьянова // Экономический журнал ВШЭ. - 2013. - Т. 17, № 2. - С. 227-255.

5. Гришина Е. Е. Дифференциация заработной платы в России: региональный и профессиональный аспекты / Е. Е. Гришина, Ю. М. Казакова, В. Ю. Ляшок / / Вопросы статистики. - 2016. - № 11. - С. 45-52.

6. Лайкам К. Э. О развитии системы статистических показателей заработной платы / К. Э. Лайкам // Вопросы статистики. - 2016. - № 10. - С. 3-11.

7. Кузнецова О. В. Структурные сдвиги в занятости и качестве жизни населения российских городов-миллионников / О. В. Кузнецова / / Проблемы прогнозирования. - 2017. - № 6. - С. 121-131.

8. Лехтянская Л. В. Формирование заработной платы на рынке труда / Л. В. Лехтянская, Т. Г. Римская // Российское предпринимательство. - 2015. - Т. 16, № 23. - С. 4281-4286. — DOI: 10.18334/rp.16.23.2131.

9. Борисов Е. Ф. Экономика : учеб. и практикум / Е. Ф. Борисов. - М. : Юрайт, 2013. - 399 с.

10. Лайкам К. Э. Методология расчета среднемесячной заработной платы / К. Э. Лайкам, З. Ж. Зайнуллина, Е. В. Зарова / / Вопросы статистики. - 2016. - № 7. - С. 52-56.

\section{REFERENCES}

1. Ozernikova T. G., Ponomarchuk M. A. The major challenges in evaluating the competitiveness of the wage policy in Russia. Izvestiya Baykal' skogo gosudarstvennogo universiteta = Bulletin of Baikal State University, 2016, vol. 26, no. 5, pp. 739-749. DOI: 10.17150/2500-2759.2016.26(5).739-749. (In Russian).

2. Gimpel'son V. E., Kapelyushnikov R. I. (eds.). Zarabotnaya plata v Rossii: evolyutsiya i differentsiatsiya [Salary in Russia: Evolution and Differentiation]. Moscow, Higher School of Economics Publ., 2008. 575 p. 
3. Lukiyanova A. L. Differentsiatsiya zarabotnykh plat v Rossii (1991-2008 gg.): fakty i ob"yasneniya [Wage Inequality in Russian Economic Transition (1991-2008): Stylized Facts and Explanations]. Moscow, Higher School of Economics Publ., 2010. 68 p.

4. Lukiyanova A. L. Earnings Inequality and Informal Economy in Russia (2000-2010). Ekonomicheskii zhurnal $V S h E=H S E$ Economic Journal, 2013, vol. 17, no. 2, pp. 227-255. (In Russian).

5. Grishina E. E., Kazakova Y. M., Lyashok V. Yu. Wage inequality in Russia: regional and occupational aspects. Voprosy statistiki = Statistical Issues, 2016, no. 11, pp. 45-52. (In Russian).

6. Laikam K. E. On the development of the system of wages statistics. Voprosy statistiki=Statistical Issues, 2016, no. 10, pp. 3-11. (In Russian).

7. Kuznetsova O. V. Structural changes in employment and the quality of life of the populations of Russian million-plus cities. Problemy prognozirovaniya = Studies on Russian Economic Development, 2017, no. 6, pp. 121131. (In Russian).

8. Lekhtyanskaya L. V., Rimskaya T. G. Salary formation in the labor market. Rossiiskoe predprinimatel'stvo = Russian Journal of Entrepreneurship, 2015, vol. 16, no. 23, pp. 4281-4286. DOI: 10.18334/rp.16.23.2131. (In Russian).

9. Borisov E. F. Ekonomika [Economics]. Moscow, Yurait Publ., 2013. 399 p.

10. Laikam K. E., Zainullina Z. Zh., Zarova E. V. Methodology for calculating average monthly wages. Voprosy statistiki $=$ Statistical Issues, 2016, no. 7, pp. 52-56. (In Russian).

\section{Информация об авторах}

Балдынова Евгения Валерьевна - старший преподаватель, кафедра бухгалтерского учета, анализа, статистики и аудита, Байкальский государственный университет, 664003, г. Иркутск, ул. Ленина, 11, e-mail: Baldynova_ev@rambler.ru.

Малютина Светлана Анатольевна - кандидат экономических наук, доцент, кафедра бухгалтерского учета, анализа, статистики и аудита, Байкальский государственный университет, 664003, г. Иркутск, ул. Ленина, 11, e-mail: MalyutinaSA@mail.ru.

\section{Для цитирования}

Балдынова Е. В. Сравнительный анализ среднемесячной реальной заработной платы работников организаций в разрезе видов экономической деятельности по Иркутской области / Е. В. Балдынова, С. А. Малютина / / Известия Байкальского государственного университета. - 2018. - Т. 28, № 3. - С. 409-418. DOI: $10.17150 / 2500-2759.2018 .28(3) .409-418$.

\section{Authors}

Evgeniia V. Baldynova - Senior lecturer, Department of Accounting, Analysis, Statistics and Auditing, Baikal State University, 11 Lenin St., 664003, Irkutsk, the Russian Federation, e-mail: Baldynova_ev@ rambler.ru.

Svetlana A. Malyutina - Ph.D. in Economics, Associate Professor, Department of Accounting, Analysis, Statistics and Auditing, Baikal State University, 11 Lenin St., 664003, Irkutsk, the Russian Federation, e-mail: MalyutinaSA@mail.ru.

\section{For Citation}

Baldynova E. V., Malyutina S. A. Comparative Analysis of Average Monthly Real Pay of Corporate Employees in Irkutsk Oblast in Terms of Types of Economic Activity. Izvestiya Baykal'skogo gosudarstvennogo universiteta $=$ Bulletin of Baikal State University, 2018, vol. 28, no. 3, pp. 409-418. DOI: 10.17150/25002759.2018.28(3). 409-418. (In Russian). 